\title{
QUANITATIVE ANALYSIS OF SOME BIOGENIC AMINES IN SALTED FISH IN RELATION TO THEIR NACL CONCENTRATIONS
}

\author{
Seham N. Hamouda * and Ghada A.k. Kirrella** \\ *Animal Health Research institute, Tanta branch. \\ *** Food Control Dep., Fac. of Vet. Med., KafrelShiekh University.
}

\begin{abstract}
The main objective of this study is to analyze the salted fish to determine the concentrations of biogenic amines in relation to their sodium chloride concentrations. Forty random samples of salted Sardine and Mugil cephalus fish" Feseekh" (20 of each) were collected from different fish markets in El- Gharbia and Kafr Elshiekh Governorates, Egypt. The collected samples were packed in polyethylene bags and stored at $-20^{\circ} \mathrm{C}$ till be analyzed for determination of their sodium chloride concentrations by titration method and biogenic amines using High Performance Liquid Chromatography(HPLC). The obtained results revealed that the mean sodium chloride concentrations were $12.72 \pm 4.02$ and $14.20 \pm 3.18$ for salted Sardine and Feseekh, respectively. On the other hand the mean concentration of histamine was $19.26 \pm 11.83$ and $16.02 \pm 10.54$ $\mathrm{mg} / 100 \mathrm{~g}$ of the examined salted sardine and feseekh samples, respectively. While the mean concentration of tyramine was $13.03 \pm$ 8.55 and $11.21 \pm 7.28$, respectively for the same examined samples. Concerning to cadeverine the mean concentration was $10.09 \pm 6.04$ and 7.84 \pm 5.64 , respectively. Comparing the obtained results with the
\end{abstract}


permissible limit (20mg/100g) recommended by FDA (2001), 35, 20 and $10 \%$ of the examined salted Sardine samples exceeded the limit for histamine, tyramine and cadaverine, while 30, 20 and 5\% of the examined feseekh samples exceeded the permissible limit for histamine, tyramine and cadaverine, respectively. This study show that there is a Significant negative correlation between sodium chloride percent and biogenic amines concentration in the examined salted fish samples for histamine While there is unsignificant negative correlation between sodium chloride percent and cadaverine concentration in the examined salted fish samples.

\section{INTRODUCTION}

Biogenic amines are of low molecular weight organic bases, they can be formed and degraded as a result of normal metabolic activity in animals, plants and microorganisms, in the latter case, biogenic amines may be used as an indicator of food spoilage. These amines are usually produced in foods by decarboxylation of amino acids as a result of decarboxylase activity of bacteria present in the food, or that contaminate the food during transporting, handling, processing and marketing (Shalaby, 1996).

Biogenic amines formation in food is objectionable due to their ability to have a direct or indirect effect on the human vascular and nervous systems. Toxicological effects such as hypertension, headache, diarrhea, rash and localized inflammation may be developed due to biogenic amines and when ingested in extreme amounts, cardiac palpitation, intracerebral haemorrhage and even death in very severe 
Quanitative Analysis Of Some Biogenic ...

cases (Rawles et al., 1996). Biogenic amines are considered precursors of carcinogenic amines such as N-nitrasosamines, and they also used as indicators of food decomposition (Mietz and Karmas, 1978). Histamine represents the major and the main cause of scombroid (histamine) poisoning, and the other biogenic amine such as tyramine, cadaverine, and putrescine, acts as potentiates of histamine toxicity (Taylor, 1988; Al-Bulushi et al., 2009; Joshi and Bhoir, 2011).

Histamine is an extremely important bioactive chemical that is indispensable in the efficient functioning of many body systems and appears in various concentrations in arrange of mammalian tissues. In humans the highest histamine concentrations are found in the skin, lung and stomach, with smaller amounts in the brain and heart, histamine is made and stored within white blood cells. When the immune system is activated in response to foreign material entering the body, histamine is the first defense chemical or correctly inflammatory mediator, released in the process called inflammation i.e. the clinical evidence that the immune system is responding (Joneja and Carmona, 2001).

Histamine exerts its effects by binding on cellular membranes in the respiratory, cardiovascular, gastrointestinal, hematological /immunological system and the skin. The symptoms usually appear shortly after the food is ingested, with duration of up to 24 hours (Taylor et al., 1989).

Food and Drug administration sets $50 \mathrm{mg} / \mathrm{kg}$ as an indicator of decomposition and 200mg/kg as hazardous (FDA, 2001), while Codex sets $100 \mathrm{mg} / \mathrm{kg}$ as an indicator of decomposition and $200 \mathrm{mg} / \mathrm{kg}$ as an indicator for poor handling and hygiene (Codex Alimentarius,2003; 
Codex Alimentarius,2007) and the European Communities microbiological criteria for food stuffs states that nine samples must be tested in batch with the mean less than $200 \mathrm{mg} / \mathrm{kg}$ with no more than two samples greater than 200mg/kg (European Commission, 2006). When estimating the toxic levels of biogenic amines, one should consider the amount of food consumed, the presence of other amines, dietary components in the food and the use of alcohol and medicines. An additional concern, especially if nitrite was to be present, putrescine and cadaverine, can react with nitrite to form carcinogens (Taylor, 1986; Ten Brink et al., 1990 and Veciana-Nogues et al., 1997).

Enterobacteriaceae has been found to be the most important histamine forming bacteria (HFB) in fish. Morganella morganii, Klebsiella pneumonia, Proteus vulgaris and Hafnia alvei are known to originate from fish implicated incidents of histamine poisoning (Lehane and Olley, 2000 and Huss et al., 2003). According to Sanchez (2008) bacteria isolated from the intestines of marine fishes are halophilic and these microorganisms can also be introduced in the addition of salt. The principal halophilic species isolated from solar salt are Bacillus and Micrococcus from rock salt.

In this respect Jesebel and Erlinda (2006) investigate histamine formation in tuna at different salt concentration. Histamine levels decreased during processing as salt concentration increased and it was above FDA standard limit of $20 \mathrm{mg} / 100 \mathrm{~g}$ at low salt concentration. Microbial counts decreased as salt concentration increased. Salt has 
Quanitative Analysis Of Some Biogenic ...

preservative action through osmotic pressure, it withdraws water from the tissue or microbial cell leading to microbial death. Also, lactic acid bacteria decreased during fermentation as salt concentration significantly affects lactic acid bacteria (LAB) which able to grow at low salt concentration.

Therefore, The main objective of this study is to analyze the salted fish available in El- Gharbia and Kafr El-shiekh Governorates, Egypt to determine the concentrations of biogenic amines in relation to their sodium chloride concentrations.

\section{MATERIALS AND METHODS}

\section{Collection of samples:}

A total of 40 random samples of salted sardine and Mugil cephalus fish "Feseekh" (20 of each) were collected from different fish markets in El- Gharbia and Kafr El-shiekh Governorates. The collected samples were transferred directly to the laboratory to determine their contents of sodium chloride and biogenic amine (Histamine, tyramine and cadaverine).

\section{Determination of Sodium chloride: $(A O A C, 2000)$ :}

Accurately, $40 \mathrm{ml}$ of $0.1 \mathrm{~N}$ Sliver nitrate solution were added to $10 \mathrm{~g}$ of the thoroughly mixed sample to precipitate the chloride as silver chloride. Moreover, $20 \mathrm{ml}$ of concentrated nitric acid were added. The contents were then gently boiled until all solids (except silver chloride) were dissolved within 15 minutes. 
Therefore, $50 \mathrm{ml}$ of distilled water and $5 \mathrm{ml}$ of saturated solution of ferric ammonium sulphate (iron alum) were added after cooling. The excess of sliver nitrate was titrated against $0.1 \mathrm{~N}$ ammonium thiocyanate till appearance of brown colour. The amount of $0.1 \mathrm{~N}$ ammonium thiocyanate exhausted in the titration was recorded.

$\Rightarrow$ Sodium chloride $\%=(\mathrm{ml}$ of $0.1 \mathrm{~N}$ silver nitrate $-\mathrm{R}) \times 0.00585 \times 10$

\section{Determination of biogenic amines:}

The levels of biogenic amines (histamine, tyramine and cadaverine) were determined using HPLC according to (Moret and Conte, 1996) as follows:

\subsection{Biogenic amine standards:}

Pure stock standards solutions of the tested biogenic amines including histamine dihydrochloride, tyramine hydrochloride and cadaverine dihydrochloride were purchased from Sigma (St. Louis, Mo 63178, USA).

\subsection{Amine extraction:}

Accurately, 25 gm of the examined sample were homogenized with $125 \mathrm{ml}$ of $5 \%$ trichloroacetic acid (TCA) for 3 minutes using a blender, and then filtrated using filter paper Whatmann No. 1. Moreover, $10 \mathrm{ml}$ of the extract was transferred into a suitable culture test tube with $4 \mathrm{gm}$ $\mathrm{NaCl}$ and $1 \mathrm{ml}$ of $50 \% \mathrm{NaOH}$, then shacked and extracted 3 times by 5 $\mathrm{ml} \mathrm{n}$ - butanol chloroform (1: $1 \mathrm{~V} / \mathrm{V})$, stoppered and shacked 
Quanitative Analysis Of Some Biogenic ...

vigorously for $2 \mathrm{~min}$. followed by centrifugation for $5 \mathrm{~min}$. at $3000 \mathrm{rpm}$. Upper layer was transferred to $50 \mathrm{ml}$ separating funnel using disposable pasture pipette. To combine organic extracts (upper layer), $15 \mathrm{ml}$ of $\mathrm{n}-$ heptane was added and extracted 3 times with $1 \mathrm{ml}$ portions of $0.2 \mathrm{~N}$ $\mathrm{HCl}$, then $\mathrm{N} \mathrm{HCl}$ layer was collected in a glass stopper tube. Solution was evaporated just to dryness using water bath at $95^{\circ} \mathrm{C}$ with air currents.

\subsection{Derivatives formation (Dansyl amines):}

Actually, $200 \mathrm{ml}$ of each stock standard solution (or sample extract) were transferred to a culture tube and dried under vacuum. About $0.5 \mathrm{ml}$ of saturated $\mathrm{NaHCO}_{3}$ solution was added to the residue of the sample extract (or the standard). The tube stopper and carefully mixed to prevent loss due to spattering. Carefully, $1 \mathrm{ml}$ dansyl chloride solution was added and mixed thoroughly using Vortex mixer. The mixture was kept in a water bath at $70^{\circ} \mathrm{C}$ for $10 \mathrm{~min}$. then, the extraction of dansylated biogenic amines was carried out using 3 times of $5 \mathrm{ml}$ portions of diethyl ether, and the ether layers were collected in a culture tube using disposable pasture pipette. The combined ether extracts were carefully evaporated at $35^{\circ} \mathrm{C}$ in dry film and dissolved in $1 \mathrm{ml}$ methanol, then $10 \mu \mathrm{L}$ injected in HPLC (Ordonez et al., 1997).

\subsection{Interpretation of HPLC (Moret and Conte, 1996):}

The most common technique for amine analysis is HPLC using derivatization before detection. Accordingly, 5 - dimethylamine - 1 naphalene sulphonyl chloride was used as derivatization reagent which 
characterized by the reaction with both primary and secondary amine groups. Furthermore, 10, 20, 30, 40 and $50 \mu \mathrm{L}$ of dansyl amine standard as well as 10 micro litres of each dansylated sample extract was used. Injection volume, $50 \mu \mathrm{l}$; flow rate, $1 \mathrm{~mL} / \mathrm{min}$; wave length, $232 \mathrm{~nm}$; column temperature, $35^{\circ} \mathrm{C}$; stop time, $15 \mathrm{~min}$; post time, 6 min.; mobile phase $500 \mu \mathrm{L} / \mathrm{min}$, retention time was 10 minutes for histamine, 11 minutes for tyramine and 6 minutes for cadaverine. However, the chromatogram was examined under long wave of ultraviolet $(254 \mathrm{~nm})$ to establish whether or not the dansyl amines of interest are present in the examined sample.

\subsection{Calculation:}

Finally, the concentration of each biogenic amine in the samples was recorded as $\mathrm{mg} / 100 \mathrm{gm}$ according to the following formula:

Amine concentration $(\mathrm{mg} / 100 \mathrm{gm})=\mathrm{CV} / \mathrm{W}$ Where,

- C: Concentration of amine standard ( $\mathrm{mg} / \mathrm{gm})$.

- V: Final dilution of sample extracts (ml).

- W: Weight of the sample in the final extracts $(\mathrm{g})$.

\section{RESULTS}

Table (1): Determination of sodium chloride\% in the examined samples.

\begin{tabular}{|c||c||c||c||}
\hline Types of samples & Min. & Max. & Mean \pm S.D. \\
\hline \hline salted sardine & 9.8 & 15.8 & $12.72 \pm 4.02$ \\
\hline feseekh & 10.9 & 18 & $14.20 \pm 3.18$ \\
\hline
\end{tabular}


Quanitative Analysis Of Some Biogenic ...

Table (2): Average concentration of histamine $(\mathrm{mg} / 100 \mathrm{~g})$ in the examined samples of salted Sardine \& Feseekh and their unacceptability according to FAD (2001) $n=20$.

\begin{tabular}{|c|c|c|c|c|c|}
\hline \multirow{2}{*}{$\begin{array}{l}\text { Types of } \\
\text { Samples }\end{array}$} & \multirow[t]{2}{*}{ Min. } & \multirow[t]{2}{*}{ Max. } & \multirow[t]{2}{*}{ Mean \pm S.D. } & \multicolumn{2}{|c|}{$\begin{array}{l}\text { Unaccepted samples } \\
\text { FDA(20mg/100g) }\end{array}$} \\
\hline & & & & NO. & $\%$ \\
\hline salted Sardine & 2.9 & 46.7 & $19.26 \pm 11.83$ & 7 & 35 \\
\hline Feseekh & 2.2 & 41.4 & $16.02 \pm 10.54$ & 6 & 30 \\
\hline
\end{tabular}

Table (3): Average concentration of tyramine $(\mathrm{mg} / 100 \mathrm{~g})$ in the examined samples of salted Sardine \& Feseekh and their unacceptability according to FDA (2001) $n=20$.

\begin{tabular}{|c|c|c|c|c|c|}
\hline \multirow{2}{*}{$\begin{array}{l}\text { Types of } \\
\text { Samples }\end{array}$} & \multirow[t]{2}{*}{ Min. } & \multirow[t]{2}{*}{ Max. } & \multirow[t]{2}{*}{ Mean \pm S.D. } & \multicolumn{2}{|c|}{$\begin{array}{l}\text { Unaccepted samples } \\
\text { FDA }(20 \mathrm{mg} / 100 \mathrm{~g})\end{array}$} \\
\hline & & & & No. & $\%$ \\
\hline salted sardine & 2.1 & 31.7 & $13.03 \pm 8.55$ & 4 & 20 \\
\hline feseekh & 1.7 & 26.1 & $11.21 \pm 7.28$ & 4 & 20 \\
\hline
\end{tabular}

Table (4): Average concentration of cadaverine (mg/100 g) in the examined samples of salted Sardine \& Feseekh and their unacceptability according to FDA (2001) $n=20$.

\begin{tabular}{|c|c|c|c|c|c|}
\hline \multirow{2}{*}{$\begin{array}{l}\text { Types of } \\
\text { samples }\end{array}$} & \multirow[t]{2}{*}{ Min } & \multirow[t]{2}{*}{ Max } & \multirow[t]{2}{*}{ mean \pm S.D. } & \multicolumn{2}{|c|}{$\begin{array}{l}\text { Unaccepted samples } \\
\text { FDA }(20 \mathrm{mg} / \mathbf{1 0 0 g})\end{array}$} \\
\hline & & & & NO. & $\%$ \\
\hline salted sardine & 1.5 & 22.1 & $10.09 \pm 6.04$ & 2 & 10 \\
\hline feseekh & 1.1 & 20.9 & $7.84 \pm 5.64$ & 1 & 5 \\
\hline
\end{tabular}


Table (5): Correlation coefficient (r) between sodium chloride\% and Biogenic amines concentration in examined samples.

\begin{tabular}{|c|c|c|c|}
\hline Types of samples & r H.S. & r T.S. & r C.S \\
\hline salted sardine & $-0.46^{*}$ & $-0.34 *$ & -0.27 \\
\hline feseekh & $-0.34 *$ & -0.05 & -0.27 \\
\hline \multicolumn{4}{|l|}{$\mathrm{r}=$ Correlation coefficient } \\
\hline \multicolumn{4}{|l|}{$\mathrm{H}=$ Histamine } \\
\hline \multicolumn{4}{|l|}{$\mathrm{T}=$ Tyramine } \\
\hline \multicolumn{4}{|l|}{$\mathrm{C}=$ Cadaverine } \\
\hline $\mathrm{S}=$ sodium chloride & & & \\
\hline
\end{tabular}

\section{DISCUSSION}

In this study, forty random samples of salted Sardine and Mugil cephalus fish" Feseekh" (20 of each) were collected from different fish markets in El- Gharbia and Kafr El-shiekh Governorates, Egypt to determine the concentrations of biogenic amine (Histamine, tyramine and cadaverine) in relation to their sodium chloride concentrations.

Sodium chloride plays an important role in microbial growth and therefore influence the activity of their amino acids decarboxylase (Zaman et al., 2009) as salt concentration significantly affects lactic acid bacteria (LAB) since these types of bacteria are generally tolerant of moderate salt concentration (Sanchez, 2008).

Table (1) demonstrate the sodium chloride concentration of the examined salted sardine and feseekh with a mean concentration of 12.72 \pm 4.02 and $14.20 \pm 3.18$, respectively. 
Quanitative Analysis Of Some Biogenic ...

The results shown in table (2) revealed that thirty five\% of the examined salted sardine samples presented a histamine concentration above $20 \mathrm{mg} / 100 \mathrm{~g}$ recommended by $\boldsymbol{F D A}$ (2001) with a mean concentration of $19.26 \pm 11.38 \mathrm{mg} / 100 \mathrm{~g}$. Furthermore, thirty\% of the examined salted feseekh samples presented a histamine concentration above $20 \mathrm{mg} / 100 \mathrm{~g}$ with a mean concentration of $16.02 \pm 10.54$.

Rapid chilling of fish directly after catching is most important factor to prevent histamine formation, especially for fish that are exposed to warmer water or air (FDA, 2001), in the meantime, the control of temperature lead to inhibit the growth of mesophilic microorganism during the storage of fish. Occurrence of psychotrophic bacteria even in adequate chilling condition can result in biogenic amines formation (Lakshmanan et al.,2002 and Rezaei et al., 2007).

Since histamine is heat resistant, once histamine is formed, it cannot be eliminated by heat treatments (Hungerford, 2010). In general there are some types of food hazards like histamine that are not easy to control at in coming material stage or during Good Hygienic Practices (GHP) and Good Manufacturing Practices (GMP) applications. Therefore, certain preventive measures and monitoring procedures must be done starting from raw material stage until final consumer. These preventive measures, time/temperature control that mainly used for critical limit for monitoring histamine formation at raw fish stage. Therefore, it is important to control histamine formation before processing. 
Table (3) shown that twenty\% of both examined salted sardine and feseekh samples had tyramine concentrations above $20 \mathrm{mg} / 100 \mathrm{~g}$ $(\boldsymbol{F D A}, 2001)$ with a mean concentration of $13.03 \pm 8.55$ and $11.21 \pm 7.28$, respectively.

The presence of other biogenic amines can potentiate the negative effect of tyramine on human health (Komprda et al., 2001). Tyramine acts mainly indirectly by releasing noradrenalin from the sympathetic nervous system which causes increase of blood pressure by peripheral vasoconstriction and by increasing the cardiac output, increase respiration and increases the blood sugar (Joosten, 1988).

Regarding to table (4) the mean concentration of cadaverine in the examined samples of salted sardine was $10.09 \pm 6.04$ where ten $\%$ of the examined samples hadcadaverine above the permissible limit $20 \mathrm{mg} / 100 \mathrm{~g}$ (FDA,2001). Moreover, the mean concentration of cadaverine in the examined samples of salted feseekh was $7.84 \pm 5.64$ whereas five $\%$ of the examined samples had concentration above the permissible limit.

Table (5) reveal that there is a Significant negative correlation between sodium chloride percent and biogenic amines concentration in the examined salted fish samples for histamine, this is agreement with (Jesebel and Erlinda, 2006). While there was unsignificant negative correlation between sodium chloride percent and cadaverine concentration in the examined salted fish samples. Concerning to tyramine there was significant negative correlation with salt in salted sardine. 
Quanitative Analysis Of Some Biogenic ...

Douglas (1970) reported that very large amounts of histamine could be given orally without causing adverse effects. He attributed this to the conversion of histamine to inactive $N$-acetylhistamine by intestinal microflora. Human subjects given up to $67.5 \mathrm{mg}$ histamine orally, in a single dose, did not produce any subjective or objective symptoms of histamine poisoning (Granerus, 1968). While (Clifford et al.,1989) fed portion of spoiled mackerel containing $300 \mathrm{mg}$ histamine to volunteers, there were no significant observable effects. (Sjaastad,1966), however, administered $36 \mathrm{mg}$ or more of histamine to subjects who subsequently developed symptoms with histamine toxicity, so they concluded that high histamine levels are able to cause toxic response, but subsequent research has indicated that other factors may also be responsible. (Ienistea, 1973) reported the deleterious effects in relation to the amount of histamine ingested at one meal as follows: 8 to $40 \mathrm{mg}$ histamine-mild poisoning, 70 to $1000 \mathrm{mg}$ disorders or moderate intensity, 1500 to $4000 \mathrm{mg}$ sever incident.

Fernandez- Salguero and Mackie(1987) stated that histamine appears not to be the sole factor in causing toxicity, as strong evidence exists that biogenic amines such as cadaverine, as well as other diamines in fish tissue can potentiate the toxic effect of histamine by inhibiting intestinal histamine-metabolizing enzymes and facilitate the transport of histamine through the intestinal wall. Some medication can release histamine; others can reduce the effectiveness of the enzyme (diamine oxidas that breaks down histamine (Maintz and Novak, 2007). As a result, the level of histamine rises and may cause symptoms, even in a person who has shown no signs of histamine intolerance in the past. 
So, we confirm the importance of biogenic amines control as an important tool to establish better conditions of preservation of salted sardine and Feseekh during their manufacturing and storage. Therefore, the greatest emphasis in the prevention of the formation of the biogenic amines should be placed on the high quality of used raw materials. Temperature and storage time of raw materials, education on hygienic handling and manufacturing of raw materials, maintaining of hygienic standards during manufacturing process and on the proper control of the individual technological steps.

\section{REFERENCES}

- Al-Bulushi, I.; Susan, P.; Hilton, C.D. and Gary, A.D. (2009): Biogenic Amines in fish: Roles in intoxication, Spoilage, and Nitrosamine Formation-AReview.Cri. Rev. Food Sci. Nutri., 49(4):369-377.

- AOAC “Association of Official Analytical Chemists" (2000): Official methods of analysis. $13^{\text {th }}$ Ed., w. Horwitz .w, (Editor), Academic press, Washington, D.C., USA.

- Clifford,M.; Wright,R.; Wright,J.; Hardy,R. and Murray,C.K. (1989): Studies with volunteers on the role of histamine in suspected scombrotoxicosis,J.Food Sci., 47,365.

- Codex alimentarius (2003): Codex standard for boiled dried salted anchovies codex stan. 236.

- Codex alimentarius (2007): Codex standard for canned sardine and sardine type products codex stan. 94-1981. 
Quanitative Analysis Of Some Biogenic ...

- Douglas, W.(1970): Histamine and antihistamines; 5Hydroxytryptamine and antagonists, in Goodman, L. and Gilman, A., eds., the Pharmacological Basis of Therapeutics, $5^{\text {th }}$ ed., Macmillan, New York, pp. 621-662.

- European Commission(EU), 2073(2006): Commission regulation (EU)No. 2073/2005 of 15 Nov. on microbiological criteria of food stuffs.

- FDA (1995): Procedures for the safe and sanitary processing and importing of fish and fishery products. Federal Register, 60: 6509665202 .

- FDA (2001): Scombrotoxin (histamine) formation. Ch. In Fish and Fishery products Hazards and Controls Guidance .3nd ed., pp. 83102. Food and Drug Administration, Center for Food Safety and Applied Nutrition, Office of Seafood, Washington, DC.

- Fernandez-Salguero, J. and Mackie, I.M. (1987): Technical note:Preliminary survey of the content of histamine and other higher amine in some samples of Spanish canned fish. Int. J.Food Sci. Technol., 22,409.

- Granerus, G. (1968): Effects of oral histamine, histidine, and diet on urinary excretion of histamine, methylhistamine, and 1-methyl-4imidazoleacetic acid in man. Scand. J. Clin. Lab. Invest., 10, suppl., 49.

- Hungerford, J. (2010): Scombroid poisoning: a review. Toxicon.; 56(2): 231-243. 
- Huss, H.H.; Ababouch, L. and Gram, L. (2003): Assessment and Management of Seafood Seafood Safety and Quality, FAO Fisheries Technical Paper 444,Rome, 230 pp.

- Lakshmanan, R.; Shakila, R. J. and Jeyasekaran, G. (2002): Survial of amine forming bacteria after the ice storage of fish $\&$ shrimp.Food Microbiol., 19:617-625.

- Lehane, L. and Olley, J. (2000): Histamine fish poisoning revisited. Int. J. of Food Microbiol.,58: 1-37.

- Ienistea, C. (1973): Significance and detection of histamine in food, in Hobbs, B. and Christian, J. H. B. ,eds., The Microbiological Safety of foods, Academic Press, New York,pp.327-343.

- Jesebel R. B. and Erlinda I. D. (2006): Influence of salt concentration on histamine formation in fermented tuna viscera (Dayok) . Food and Nutri. Sci., 3,201 -206.

- Joneja, J.M.V. and Carmona, S. C. (2001): Outcome of a histaminerestricted diet based on chart audit. J. of Nutri. and Environmental Med.; 11(4):249-262.

- Joosten, H.M.L.G. (1988): the biogenic amine contents of dutch cheese and their toxicological significance . Neth . Milk Dairy J.,42:25 -42 .

- Joshi, P.A. and Bhoir, V.S. (2011): Study of Histamine Forming Bacteria in Commercial fish samples of Kalyan city. Int. J. Cur. Sci. Res., 1(2):39-42. 
Quanitative Analysis Of Some Biogenic ...

- Komprda, T.; Neznalova, J.; Standara, S. and Bover-Cid, (2001): Effect of starter culture and storage temperature on the content of biogenic amines in dry fermented sausage policean .J. Meat Science, $59: 267$ - 276 .

- Maintz, L. and Novak, N. (2007): Histamine and histamine intolerance. Am J Clin Nutri,. 85:1185-1196.

- Mietz, J.L. and Karmas, E. (1978): Polyamine and histamine content of rock fish,salamon,lobster and shrimp as an indicator of decomposition.J. AOAC, 16(1): 139-145.

- Moret, S. and Conte, L. (1996): High performance liquid chromatographic evaluation of biogenic amines in foods. J. Chromatography, 729:363-369.

- Ordonez, A., Francisco, C., Paloma, T. and Yolanda, B. (1997): Formation of biogenic amines in food products. J. Food Protect., 60 (11): 1371-1375.

- Rawles, D.D.; Flick G.J. and Martin, R.Y. (1996): Biogenic amines in fish and shellfish. Adv. Food Nutri.Res.39:329-365.

- Rezaei, M.; Montazeri, N.; Langrudi,H. E.; Mokhayer, B.; Parviz, M. and Nazarinia A. (2007): The biogenic amines and bacterial changes of farmed rainbow trout ( Oncorhynchus mykiss) stored in ice. Food Chem., 103: 150-154.

- Sanchez,P. C. (2008): Philippine Fermented Foods.Principle and Technology. The University of the Philippines Press, Quezon City. 
- Shalaby, A.R. (1996): Significance of biogenic amines to food safety and human health .Food research Int., 29: 213 - 231.

- Sjaastad, O. (1966): Fate of histamine and N-acetylhistamine administered into human gut. Acta Pharmacol. Toxicol., 24, 189.

- Taylor, S. (1986): Histamine food poisoning: toxicology and clinical aspects, Critical Reviews in food Sci. and Nutri., 17,CRC Press, Boca Raton, p. 91.

- Taylor, S.L. (1988): Marine toxins of microbial origin. Food Technol., March, pp. 94-98.

- Taylor, S.L.; Stratton, J. E. and Nardlee, J.A. (1989): Histamine poisoning (scombroid fish poisoning): an allergy- like intoxication.Clinical Toxicol.; 27:225-240.

- Ten Brink, B.; Damink, C.; Joosten, H.M.L.J. and Huis J.H.J. (1990): Occurrence and formation biologically active amines in foods, Int. Food Microbiol., 11,73.

- Veciana-Nogues, M.; Marine-Font, A. and Vidal-Carou, M.C. (1997): Biogenic amines as hygienic quality indicators of tuna. Relationships with microbial counts, ATP-related compounds, volatile amines and organoleptic changes, JI. Agric. Food Chem., 452036.

- Zaman,M.Z.;Abdulamir, A. S.;Bakar,F.A. ;Selamat,J. and Bakar,J. A. (2009): Microbiological, Physicochemical and Health Impact of High Level of Biogenic Amines in Fish Sauce. American J. of Applied Sci., 6 (6): 1199- 1211. 
التحليل الكمي لبعض الأمينات الحيوية في الأسماك المملحة و علاقتها بتركيز ملح الطعام بها

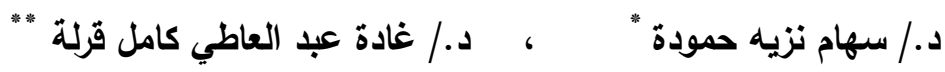

* معهد بحوث صحة الحيوان فرع طنطا

*" قسم مراقبة الأغذية- كلية الطب البيطري - جامعة كفر الثيخ.

أجريت هذه الدراسة على عدد 40 عينة عشوائية من السردين و الفسيخ المملح (20 من كل

منتج) من أسواق محافظتي الغربية وكفر الثيخ لفحصها لتقدير نزكيز نسبة ملح الطعام باستخدام طريقة التقطير، وكذلك قياس تركيز الأمينات الحيوية (الهستامين، التنيرامين و الكادفرين) باستخدام جهاز الكروماتوجرافى، و مدى ارتباط نركيز ملح الطعام بوجود الأمينات الحيوية و مقارنتها بالحد المسموح بة في المواصفات القياسية العالمية. وقد تبين من الدراسة أن متوسط نسبة ملح الطعام فى كل من السردين والفسيخ 4.02 12.72 و 3.18 × 14.20 على التوالي وقد كان متوسط نواجد الهستامين، التنيرامين و الكادفرين فى السردين و الفسيخ 11.83 ×19.26 ،10.54 × 16.02،

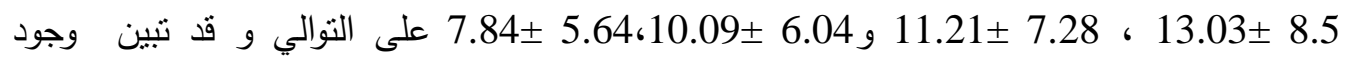
الهستامين ، التيرامين و الكادفرين فى السردين الملح نزيد عن القياسات العالمية (2001) FDA بنسبة 35\%، 20\%، 10\% على التوالي بينما كان متوسط تواجد الهستامين، التبرامين والكادفرين فى الفسيخ المملح تزيد عن القياسات العالمية (2001) FDA بنسبة 30\%، 20\%، 5\% على التوالي. وتم مناقثة الأهمية الصحية من نواجد تلك الأمينات الحيوية في الأسماك المملحة وكيفية الحد من وجودها حفاظا على صحة المستهلك. 